UDC: 378. 366.634: 004

\author{
Olena G. Glazunova \\ National University of Life and Environmental Sciences of Ukraine, Kyiv, Ukraine \\ ORCID 0000-0002-0136-4936 \\ o-glazunova@nubip.edu.ua
}

Olena G. Kuzminska

National University of Life and Environmental Sciences of Ukraine, Kyiv, Ukraine ORCID 0000-0002-8849-9648

o-kuzminska@nubip.edu.ua

Tetyana V. Voloshyna

National University of Life and Environmental Sciences of Ukraine, Kyiv, Ukraine ORCID 0000-0001-6020-5233

t-voloshina@nubip.edu.ua

Taisia P. Sayapina

National University of Life and Environmental Sciences of Ukraine, Kyiv, Ukraine ORCID 0000-0001-9905-4268

t_sayapina@nubip.edu.ua

Valentyna I. Korolchuk

National University of Life and Environmental Sciences of Ukraine, Kyiv, Ukraine ORCID 0000-0002-3145-8802

kololchuk@nubip.edu.ua

\title{
E-ENVIRONMENT BASED ON MICROSOFT SHAREPOINT FOR THE ORGANIZATION OF GROUP PROJECT WORK OF STUDENTS AT HIGHER EDUCATION INSTITUTIONS
}

\begin{abstract}
Materials of the article are devoted to the experience of implementing cloud services in the process of training students at the National University of Life and Environmental Sciences of Ukraine. The latest research in the field of designing and creating e-environments for the organization of group project work has been analyzed. The e-environment model based on Microsoft SharePoint is developed and the method of using Office 365 cloud services in a single eenvironment for organizing group project work of students is given. This article offers the developed criteria and selected tools for assessing the effectiveness of using the e-environment for the organization of group project work. It presents the materials and analysis of the results of applying the project method in the course of studying the academic discipline "Information Technologies" at the National University of Life and Environmental Sciences of Ukraine. It also defines the advantages of applying e-environment based on Microsoft SharePoint for the organization of students' project work.
\end{abstract}

Keywords: higher education institutions, Microsoft information technology, cloud services, eenvironment, project method, group work, professional and personal competences.

\section{INTRODUCTION}

Statement of the problem. One of the most effective technologies for the formation of professional competences and skills of the 21 st century students at universities is the project method, the use of which in the educational process provides a possibility to develop professional, self-education and communicative competences.

For the organization of students' group project work we need services for communication, collaborative work, planning of project stages, etc. Provided that the students' field of study is taken into account as well as their professional and educational 
needs when designing a project, the students further actively use these services for communicating and organizing their own personal virtual environment.

The number of individual services and integrated solutions from commercial companies that can be used to implement collective projects is constantly increasing. Therefore, the research hypothesis was based on the following assumption: when conducting training projects, a properly organized e-environment would contribute to more effective planning of project phases, organization of communication and collective work on the creation of the final product, and, accordingly, the application of the project method as a whole.

Analysis of latest research and publications. The works by M. Knoll [4], W. Scholler, J. D. Weiss, T. Grady Roberts, and Julie F. Harlin [5] consider the theoretical and practical aspects of the application of the project method in the student's educational activity. O. Karabin believes that the project activities of future specialists in the field of information technology is one of the components of the educational process aimed at forming skills in the information space, professional self-development, professional competence, creativity, information culture, self-directed activities aimed at improving and systematizing knowledge, professionally meaningful skills and abilities that will help to successfully operate in professional activity and develop career paths [6].

The researchers N. Morze and L. Varchenko-Protsenko investigated the Wiki-based environment as an effective platform for implementing educational technologies focused on the active work of students and educators, all participants in the educational process, which enables to create projects of different types (training, practice, cooperation, communication, presentation of materials, project methodology, development of critical thinking, etc.). Such an environment has a positive effect on the formation of students' skills in cooperation, communication and critical thinking [7].

The problem of using cloud computing technologies in education is considered in the research by Al Alaa N. Tashkandi, Ibrahim M. Al-Jabri [1], Mohssen M. Alabbadi [2]. G Suit for Education and Microsoft Office 365 are among the most well-known platforms used in educational process, including the organization of students' project work. They represent cloud technologies, the use of which is intended to improve the efficiency of communication and collaboration between the student and the educator. Microsoft SharePoint is one of the services of $\mathrm{O} 365$, which makes it possible to integrate all the necessary tools for project work in a single portal. Aleksandar Skendzic, Bozidar Kovacic in their research feature the peculiarities of the MS Office 365 platform based on the "cloud" concept as a cost-effective product and compare it with Google Apps [3]. Adrian Ellison and Mauli Arora describe in their research the experience of using Microsoft Office 365 services for team-work so that students can combine social learning with their academic study. The authors focus on attracting students to SharePoint-based portal design [8]. Bruce Worobecand, Robert Bryant cover in their works the issue of motivation for developing a SharePoint site for use in computer science courses [9]. Laura Atkins and Carey Cole describe the concept of collaboration on content sharing, feedback and iteration by means of using Microsoft SharePoint; the instructor can guide students how to use it [10].

The purpose of the article is to test the effectiveness of Microsoft SharePoint-based eenvironment for organizing group-based training projects as case studies for the acquisition of hard skills and soft skills by future IT professionals.

\section{FINDINGS}

\subsection{The use of Office 365 cloud technologies for learning IT}

Taking into account that a current competitive specialist, regardless of the specialty, should possess professional and personal skills, both of them must be viewed as expected 
results (learning objectives). Studies conducted at Harvard and Stanford universities have shown that only $15 \%$ of career success is provided by the level of hard skills, while the other $85 \%$ are provided by soft skills [11].

Enrichment of the learning process with modern ICT tools, in particular the cloud services of G Suit for Education and Microsoft Office 365, leads to a close link between the individual trends in information technology development and teaching methods through the impact on their technological subsystems [12]. By making a significant impact on the means of training, cloud technologies also affect other components of the technological subsystem of the methodological system, in particular the methods and forms of the organization of teaching process. The business world today values collaboration and teamwork skills (forms of learning) such as those found in the area of project management, business process reengineering, quality circles, etc. In response, the use of group projects (teaching methods) permits many curricula today with varying consequences and level of success. Technology claims to enhance collaboration in distributed teams but its success has been a challenge for organizations [13].

The problem is more urgent for the informatics academic disciplines in which ICT serve both as a means of learning and as an object of study, therefore, innovational changes in information technologies affect not only the technology subsystem, but also the content and purpose of learning.

Table 1 provides examples of the use of Office 365 tools when studying the Information Technology discipline at the National University of Life and Environmental Sciences (NUBiP) of Ukraine.

Table 1

O365 Tools for Different Tasks and Methods of Performance Assessment

\begin{tabular}{|l|l|l|l|l|}
\hline $\begin{array}{c}\text { Types of } \\
\text { educational } \\
\text { activity }\end{array}$ & $\begin{array}{c}\text { Examples of } \\
\text { tasks }\end{array}$ & Main tools & $\begin{array}{c}\text { Soft skills/ } \\
\text { Assessment } \\
\text { methods }\end{array}$ & $\begin{array}{l}\text { Hard skills / } \\
\text { Assessment methods }\end{array}$ \\
\hline $\begin{array}{l}\text { Laboratory work } \\
\text { (individual task) }\end{array}$ & $\begin{array}{l}\text { "Workplace of a } \\
\text { modern } \\
\text { specialist": to } \\
\text { choose hardware } \\
\text { and software in } \\
\text { accordance with } \\
\text { a certain } \\
\text { specialty and } \\
\text { modern trends of } \\
\text { ICT } \\
\text { development }\end{array}$ & $\begin{array}{l}\text { Oncel Online } \\
\text { Oner Point } \\
\text { OneDrive }\end{array}$ & $\begin{array}{l}\text { Situational } \\
\text { awareness [14] }\end{array}$ & $\begin{array}{l}\text { Knowledge of the } \\
\text { basics of PC } \\
\text { architecture and } \\
\text { computer networks, } \\
\text { the ability to apply it } \\
\text { in the process of } \\
\text { providing IP } \\
\text { technical support / } \\
\text { Assessment by the } \\
\text { educator }\end{array}$ \\
\hline $\begin{array}{l}\text { Laboratory work } \\
\text { (collective task) }\end{array}$ & $\begin{array}{l}\text { "Overview of } \\
\text { the IT labor } \\
\text { market of } \\
\text { Ukraine": based } \\
\text { on the analysis } \\
\text { of the labor } \\
\text { market to create } \\
\text { a portrait of a } \\
\text { modern IT } \\
\text { specialist }\end{array}$ & Sway & $\begin{array}{l}\text { Management skills / } \\
\text { sociometric } \\
\text { technology } \\
\text { (developed by } \\
\text { J. Moreno) [15] }\end{array}$ & $\begin{array}{l}\text { Knowledge of the } \\
\text { principles, methods } \\
\text { and algorithms of } \\
\text { computer graphics, } \\
\text { the ability to apply it } \\
\text { during the } \\
\text { development of } \\
\text { graphical interfaces } \\
\text { of human interaction } \\
\text { with the computer / } \\
\text { Assessment by the } \\
\text { "peer-to-peer" }\end{array}$ \\
\hline
\end{tabular}




\begin{tabular}{|l|l|l|l|l|}
\hline & & & $\begin{array}{l}\text { technology (Office } \\
\text { 365) }\end{array}$ \\
\hline Individual work & $\begin{array}{l}\text { "Informal } \\
\text { education of the } \\
\text { future specialist } \\
\text { in Information } \\
\text { technologies": to } \\
\text { formulate an } \\
\text { individual plan } \\
\text { of non-formal } \\
\text { education } \\
\text { according to the } \\
\text { chosen specialty }\end{array}$ & OneNote & $\begin{array}{l}\text { Personal } \\
\text { effectiveness / test } \\
\text { on time } \\
\text { management skills } \\
{[16]}\end{array}$ & $\begin{array}{l}\text { Knowledge of } \\
\text { modern technologies } \\
\text { and tools for the } \\
\text { development of } \\
\text { software systems, } \\
\text { ability to apply them } \\
\text { at all stages of the life } \\
\text { cycle / Collective } \\
\text { assessment }\end{array}$ \\
\hline
\end{tabular}

In the National University of Life and Environmental Sciences of Ukraine, under the license of Microsoft Enrollment for Education Solutions, Microsoft services are effectively used in the learning process as additional resources to provide students with training material and tools for performing various types of educational activities, in particular for performing laboratory and independent work that can be based on individual and group tasks [18]. The application of the technology of formative assessment in the process of teaching Informatics allows you to get data on the students' progress, which can be used as feedback for the correlation the learning process [19].

\subsection{Pedagogical design of the collective project}

The experience of applying cloud means of learning [20] is the basis for the "revision" of the methodological training system - increasing the share of group and active forms of learning activities of students to intensify their independence in the pursuit of knowledge and mastery of skills and technology integration of classroom and extracurricular work using blended learning.

Given that the use of Soft Skills is possible only possessing the ability to use a variety of behavior models, comprehensively understand their own and common interests, prioritize and make choices, the application of the project method in the process of teaching Informatics disciplines is seen as a promising one (it is the subject of this article, but generally not limited to it).

Here is an example of a collective project that was offered to the first-year students majoring in Computer Science, Software Engineering and Computer Engineering within the framework of teaching the academic discipline Information Technologies (http://elearn.nubip.edu.ua/course /view.php?id=2129). An example of a page of an electronic course of the discipline Information technology is presented in Fig. 1.

The aim of the project Education of the Modern IT-specialist is:

- acquaintance of the student with the possibilities of the IT-specialty, current demands at the labor market;

- formation of the student's personal educational environment;

- building a training trajectory for the IT-student.

Key questions: successful IT-specialist, what is he/she like?

Thematic questions:

- How can we measure success?

- Which profession in the sphere of IT can be chosen?

- How do I plan (being a student) to advance my professional development? 


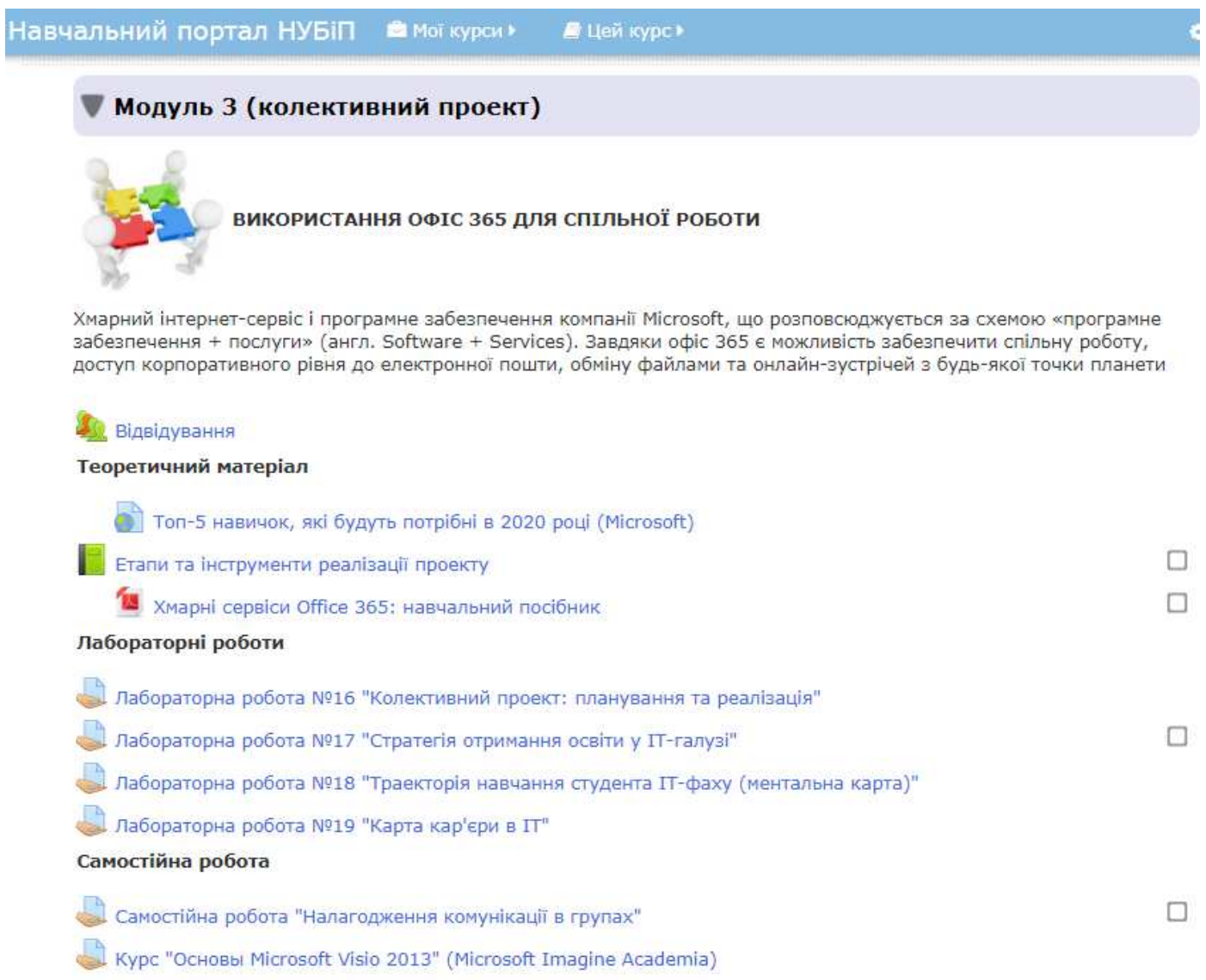

Fig. 1. A page of an electronic course of the academic discipline Information Technologies

The choice of the topic of the projects aims to boost the motivation to the learning process according to the selected field of study, to promote conscious professional choice and increase responsibility for the results of their own education and professional growth.

The tasks of the project:

- to analyze the modern IT education in Ukraine and worldwide: the form of presentation of results: abstract, hard skills: the ability to apply knowledge of methods of collecting, processing, analysis, systematization and storage of scientific and technical information;

- to make a portrait of a modern IT specialist: the form of presentation of results: poster, hard skills: the ability to apply the methods and principles of computer animation;

- to build a model of the trajectory of student's IT training: the form of presentation of results: mental card, hard skills: the ability to use modern information and communication technologies and software for project creation, analysis, support and management; to create an IT career map (for a certain profession, for example, a web developer): form of presentation of results: an interactive presentation (review of the IT labor market), speech therapy; hard skills: the ability to apply knowledge of the principles of web technologies and methods and tools for their use in solving problems.

The formulation of the topical issue "How to become a successful specialist" was preceded by acquaintance of students with academic disciplines, which are envisaged by the curriculum, the definition of professional and personal skills of students who are in demand on the modern labor market.

The proposal in the context of this work is to create a site that hosts documents and resources that include the selection of on-line courses, professional blogs, forums for each 
discipline that will provide formal and informal education for an IT-student, identify tools for optimizing the IT-specialist, creation of an IT career map for further professional identification, presentation of a proposal, web resource for discussion and evaluation of results.

This way the students are given an opportunity to work on the tasks of real projects, which increases their motivation and satisfaction with the learning process. The technology of doing such project tasks stipulated activities at certain stages, which resulted in the development of professional, communicative, interpersonal, leadership skills, teamwork and time management skills.

The phases and tools for organizing the project work of students are studied in [21]. To summarize, we distinguish five phases of the project implementation, namely: task setting (1), tools analysis (2), environmental design (3), project implementation (4), presentation of the project (5). Fig. 2 shows the project implementation phases and the corresponding tools that are appropriate for each of them.

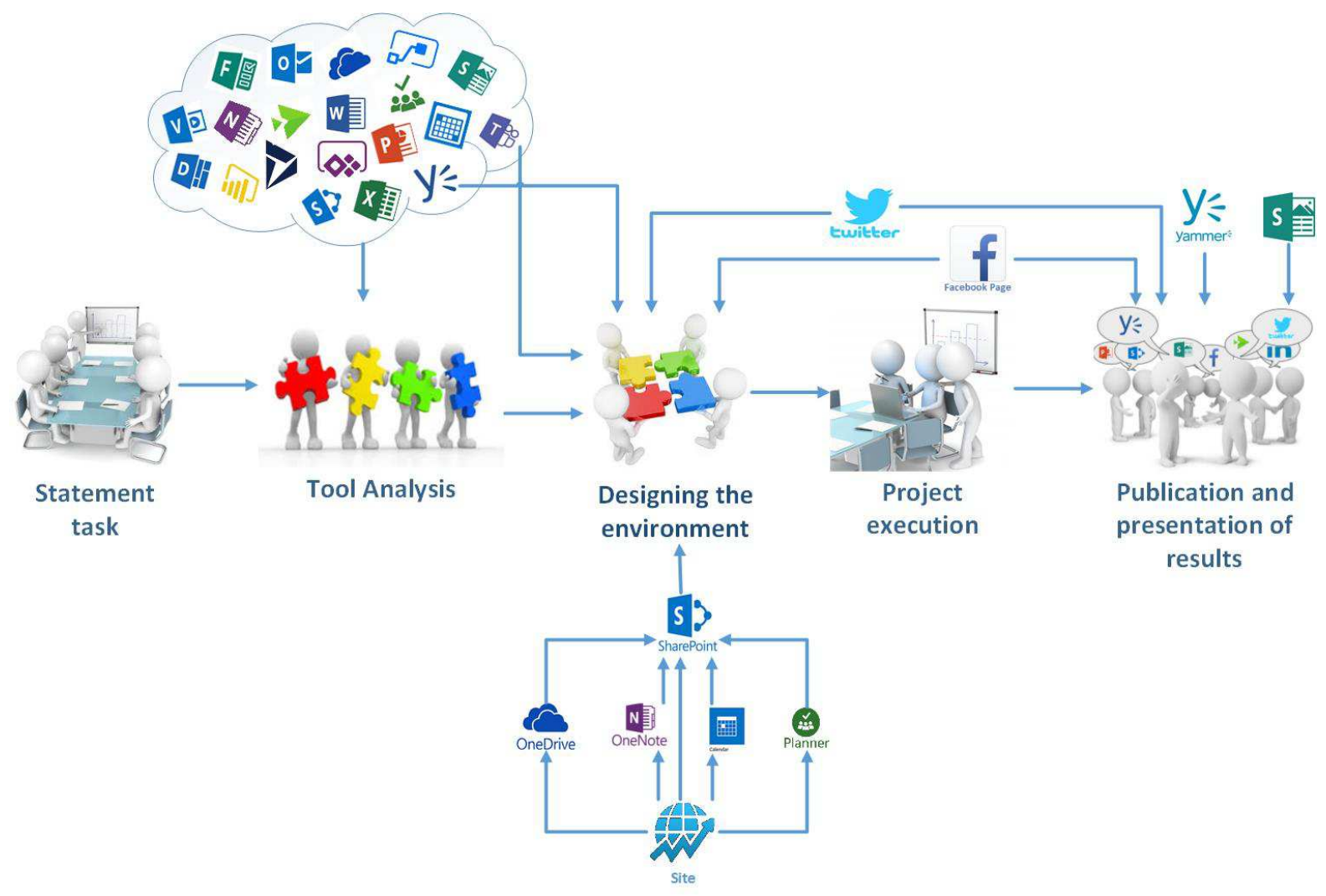

Fig. 2. Phases of group project work execution

At the phase of the task setting, the students get acquainted with the themes, purpose, tools and methods of realizing the objectives of the project; define the sources of information and the form of presentation of the results. Upon completion of this phase, the students team up, distributing tasks among participants. In this case, the educator acts as a facilitator. Depending on the composition of the academic group and by the students' agreement, teaming up for the project can be done in different ways: by drawing lots, by open vote or by consideration of vacancies for certain roles (for example, project manager, system analyst, designer, e-content manager, etc.).

At the phase of tools analysis, students analyze the tools of the cloud service Office 365 , their functional capabilities for project implementation. To determine the functionality, 
you can use the online help (https://support.microsoft.com/uk-ua) or take a course at Microsoft Imagine Academy, namely: work with Outlook 2016; work with the digital notebook OneNote; Fundamentals of Office 365 for information workers.

The advantages of using the identified services are tested by the students in an empirical way. The examples of using the services Planner and Calendar in groups are presented in Fig. 3 and 4.

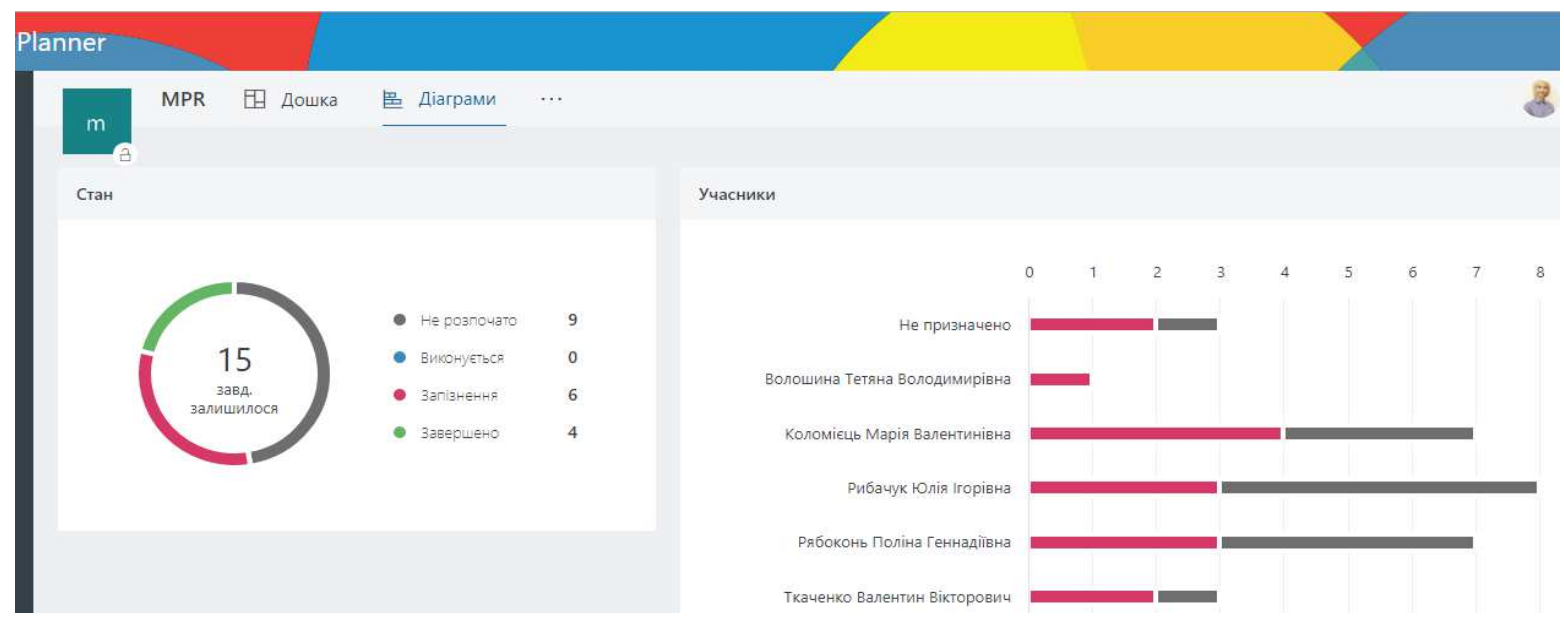

Fig. 3. An example of using the service Planner during the group project work

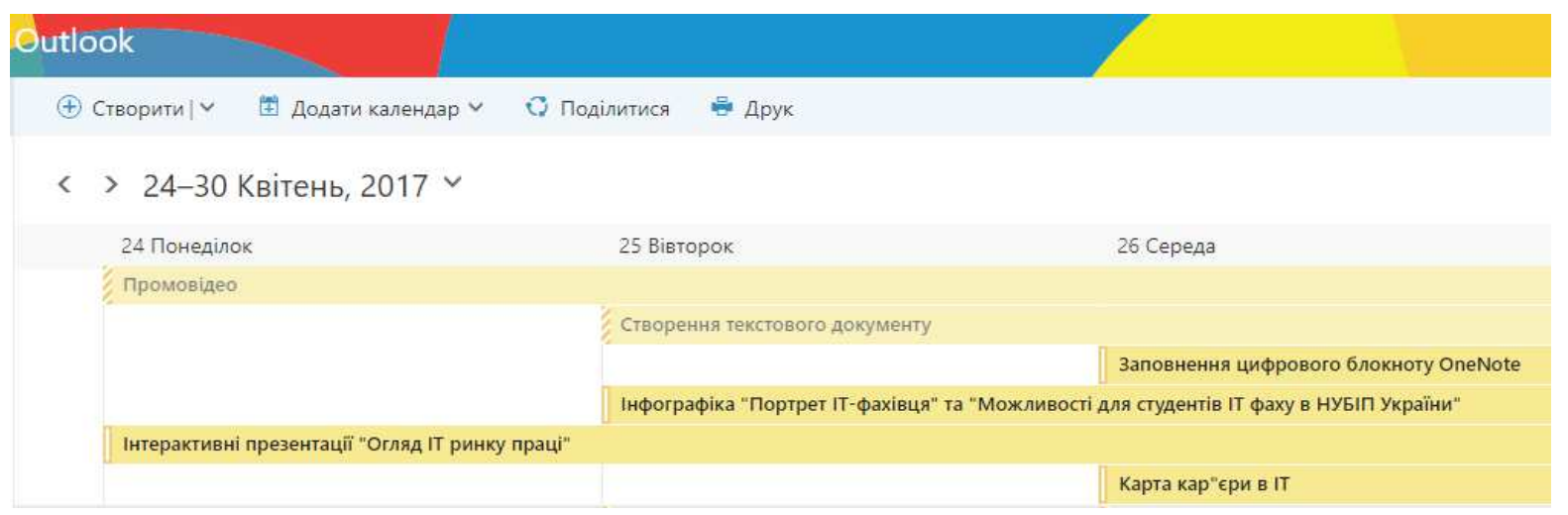

Fig. 4. An example of using the service Calendar during the group project work

At the phase of environmental design, students design their own environment for group project work. The only restriction for students (under the terms of an experiment) is the mandatory use of Microsoft services. Students must independently create an environment based on services MS Office 365, MS SharePoint or use the connector function to connect external services or applications (Fig. 5). For the search of the experts on the issues of connecting and using separate services or complex solutions the students are offered to address the thematic forums (for example, the community of developers and technical enthusiast Microsoft Channel 9: https://channe19.msdn.com/, Developer Network (blog): https://blogs.msdn.microsoft.com/, Developer Network (forum): https://social.msdn.microsoft.com/Forums/en-US/home, community of programmers: https://dou.ua/). 


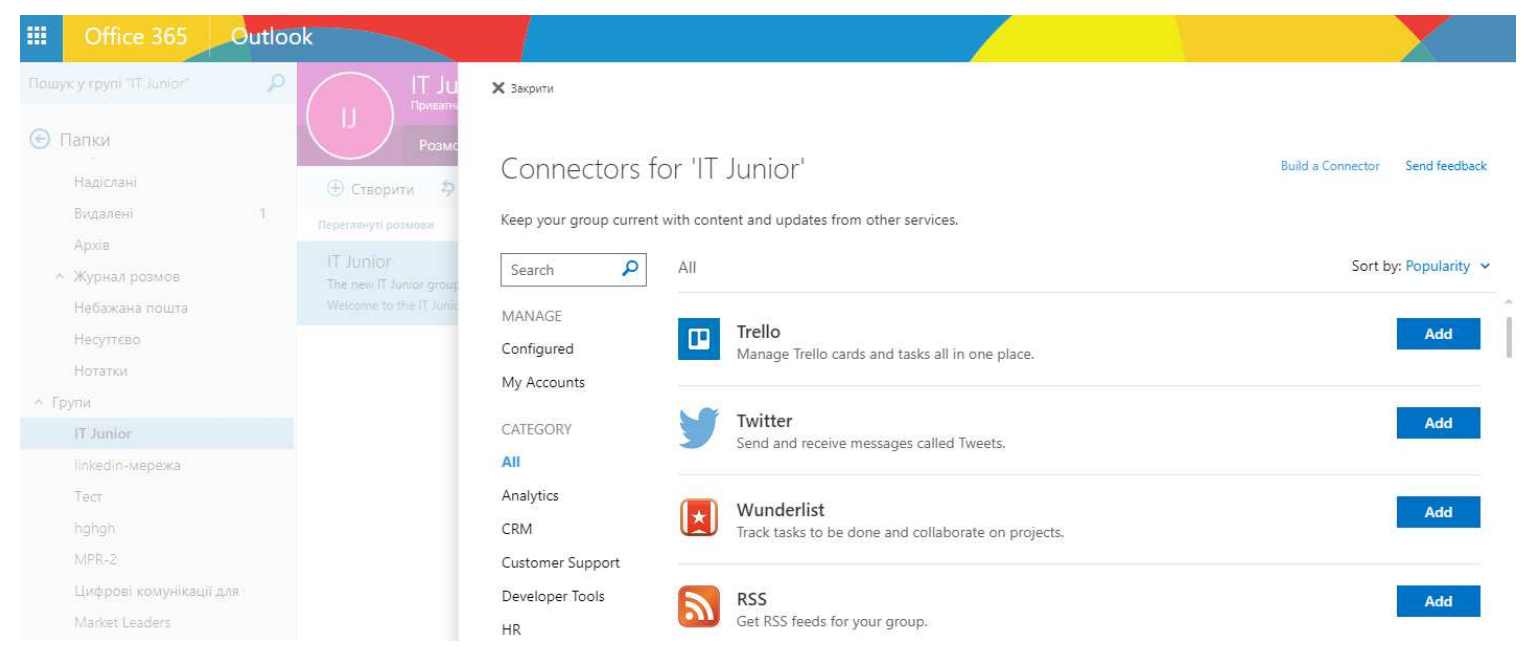

Fig. 5. An example of building connections with other services

The project implementation phase is carried out by students independently, the instructor supervises the process and provides consulting (classroom or on-line upon agreement with the students). At this phase, the instructor conducts on-line discussions with the students via Skype for Business, Yammer social network, Outlook with the aim of monitoring the student's independent work on project tasks. In addition, each group should have one thematic webinar devoted to discussing the current results (topics and time are agreed in advance).

Presentation of the project takes place in the classroom in the form of a public speech, Sway presentations. Students post their own portfolios of projects to web site (Fig. 6), creating pages with different content, sharing ideas, using images, Excel, Word and Power Point documents, embedding interactive Sway presentations, surveys, videos and other means. Students also post their results on the social network Yammer and Facebook Page, Twitter, provided they have joined the designed e-environment.

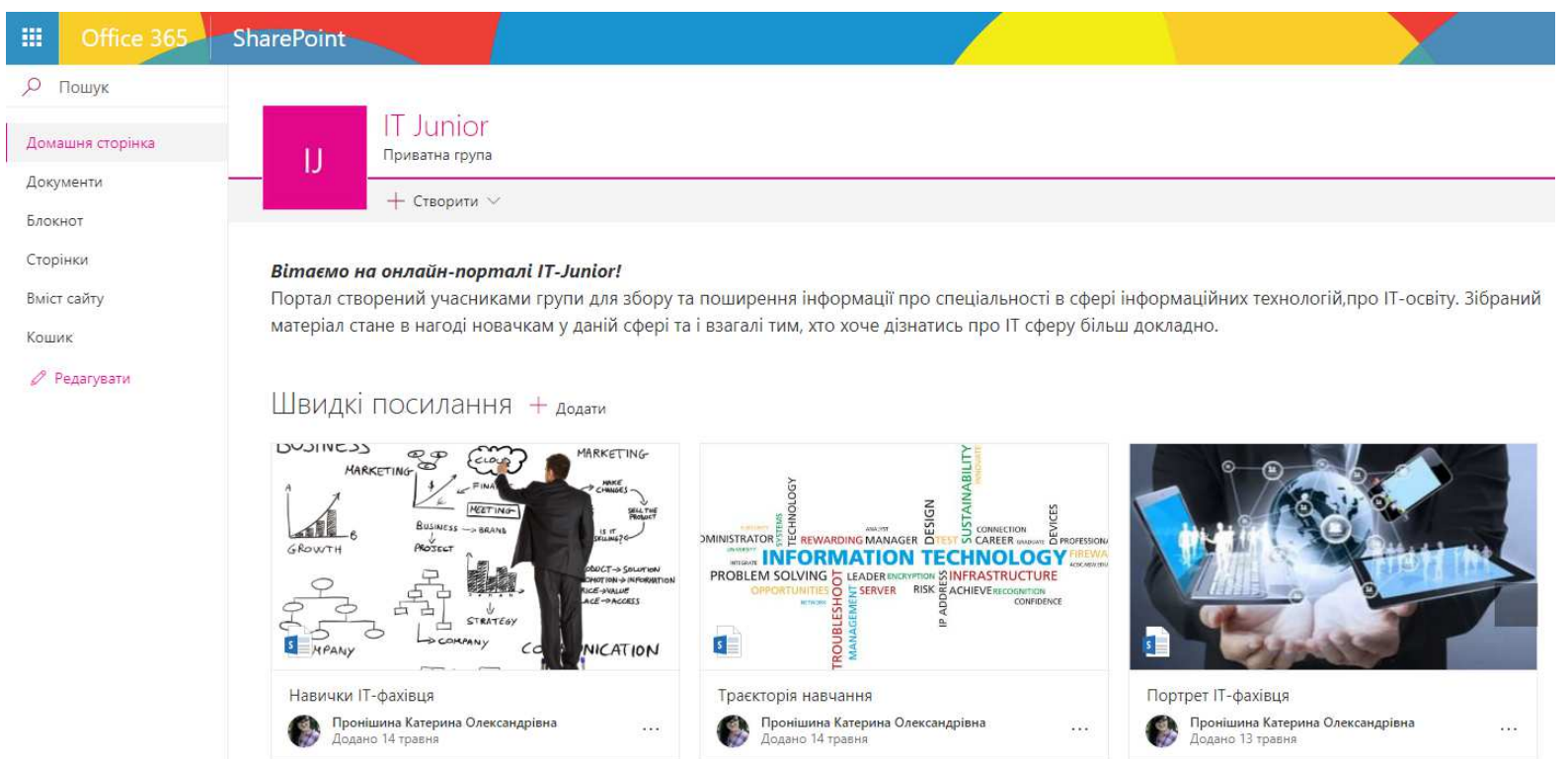

Fig. 6. An example of creating a home page (project result)

The terms for implementing the project phases, the timetable for consultations, presentation of the results and the criteria for their assessment should be planned and made 
public prior to the start of the project. Involvement of external experts (for example, from potential employers or Microsoft representatives) helps to motivate students and increase responsibility for project implementation.

\subsection{Results of the experiment}

By the results of the environmental design phase the redistribution of groups took place and two streams of students were identified. The control groups (stream 2) did the project using the services and tools they chose independently. Predominantly, these were Office 365 services, because such services were used by students for doing course tasks (Table 1). Experimental groups (stream 1) worked on project implementation in a projected eenvironment based on Microsoft SharePoint, which integrated all the services necessary for group project work. The model of this environment is presented in Fig. 7.

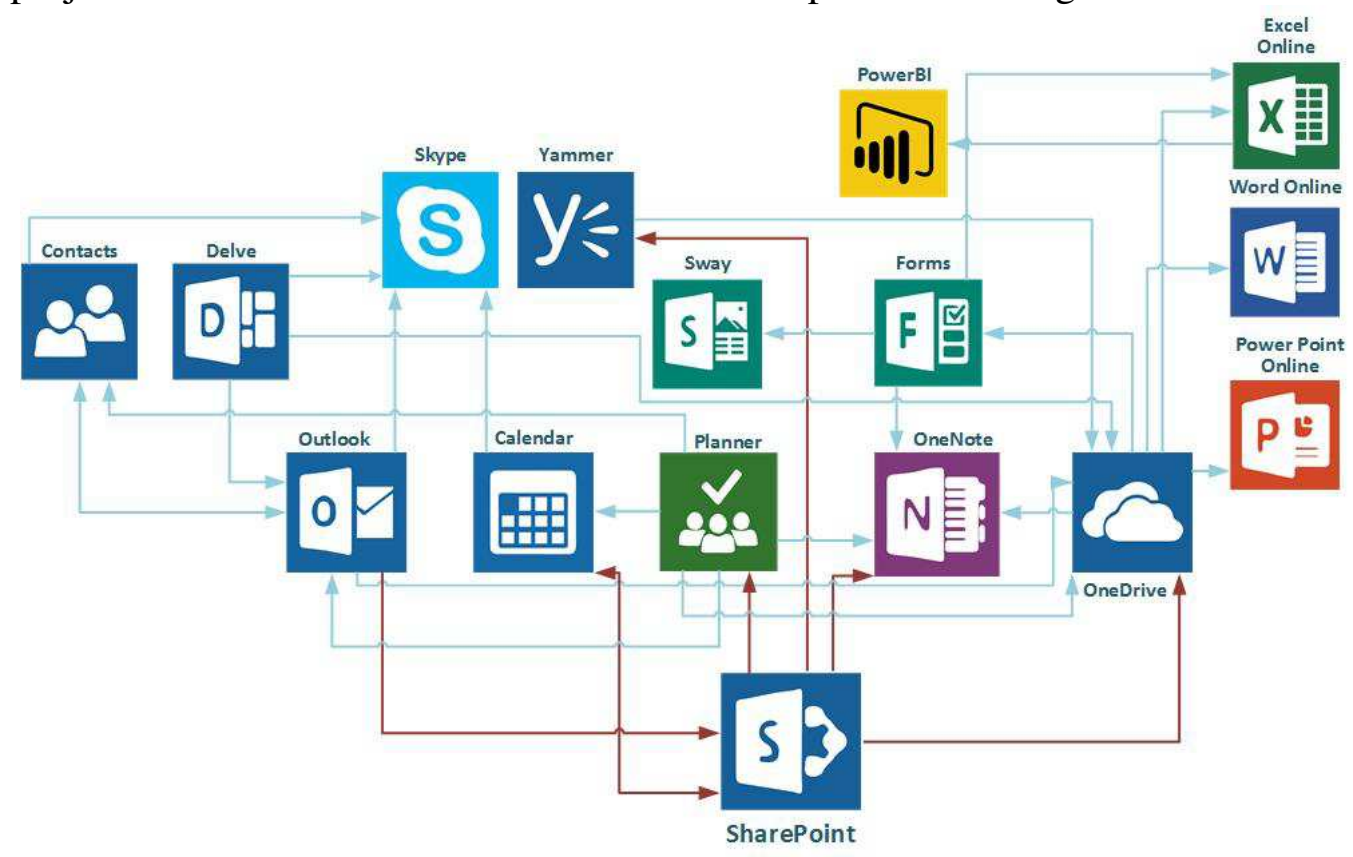

Fig. 7. The environment model for the organization of group project work on the basis of Microsoft SharePoint

The students of the experimental groups (stream 1) chose SharePoint as the environment, which is a corporate portal for joint work in real time. Let us present the brief description of the advantages of this environment (based on the results of students' interviews). One of the main tools of joint work in SharePoint is the teams' sites. The content, information, programs and the like are posted there. The leaders of the teams or projects can create a corresponding resource in SharePoint and add other users. Such added students receive description, requirements and other information; have the possibility to exchange files, data, news and resources. A wide range of opportunities in SharePoint combined with Yammer contacts and chats help to spread the information within the group very quickly. The students can also safely and easily cooperate with the participants of their team - both at their higher educational institution and beyond - via their PCs, Mac computers and mobile devices.

While performing group project work the students used embedded services Office 365, which are combined in portal SharePoint, which can be assessed by the student via Outlook (@it.nubip.edu.ua). The above-mentioned service is also intended for work with the calendar, which gives a possibility to stay up-to-date, plan appointments, share information about the time, when the students are available for sessions, plan sessions and work with notifications. 
Joint calendars give the possibility to the group to plan their sessions and instantaneously reply to the invitations of other participants. Skype is integrated into the services Calendar and Outlook, it enables the students and educators to make voice or video-calls, exchange swift messages and arrange video-conferences and allows common viewing from the screen, conducting on-line presentations.

While using the Contact services students can make a selection of users who are members of a group created in SharePoint. Thanks to Delve, students created a board where they collected all project documents for common sharing. The SharePoint portal has its own cloud storage OneDrive, which enables students to collaborate on documents and manage folders and files within a specific project as opposed to a separate OneDrive service in Office 365. Owing to the services Word Online, Excel Online, Power Point Online the students can perform joint group task. There is also an integrated OneNote digital notebook on the portal. The tasks of the group project work of the students include a lot of information and this portal helps students to store different information on any device, to arrange the teaching materials in one digital notebook.

The Planner service, which is integrated into SharePoint enables the students to distribute and plan, share information and the process of project implementation. One of the main tasks that Planner solves is the visual display of group work, organization of a corporate event, team scheduling, task tracking. It can be used to attach Word, Excel, and PowerPoint files and keep them available for editing.

The students can create reports, tasks, projects and their portfolios with the help of Sway service. In addition, the Sway presentation can be embedded in an existing user web resource, the SharePoint portal that provides html-code insertion. With this purpose Facebook Page, Twitter, and Yammer are embedded in SharePoint when designing an e-environment.

The Forms service allows all group members to create their own surveys, registration forms, and the like. Form authors can invite other users to fill in forms using any web browser, including the ones on mobile devices, view results and form data (i.e., results), and can also export results to Microsoft Excel for additional analysis in Power BI. Power BI is a business intelligence service which allows you to visualize and analyze data, build interactive reports, turn educational data into spectacular visual elements and interactive reports, organize information and share thoughts so you can focus on key issues.

With the aim of open communication and better understanding among students and between students and the educator, the students, on being connected to their own portal Yammer social network, have the opportunity to discuss their ideas, share news and use the experience of their colleagues.

In the process of performing the tasks of the project, the students not only consolidate hard skills, but also formulate patterns of their own behavior in situations of group work. In particular, time management skills were formed at the phases of project planning and monitoring. Interpersonal competencies were developed at the phases of role distribution, project planning, project implementation and monitoring. Strategic skills of the students were developed at the phase of posting and presenting project results.

Since the soft skills are difficult to trace, students used appropriate tests for monitoring and self-assessment (Table 1). Test results of one of the teams are shown in Fig. 8 and 9. 


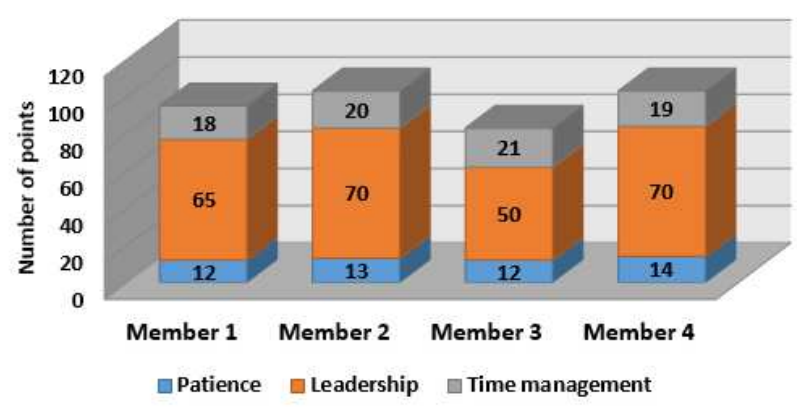

Fig. 8. Results of determining the level of soft skills before the project

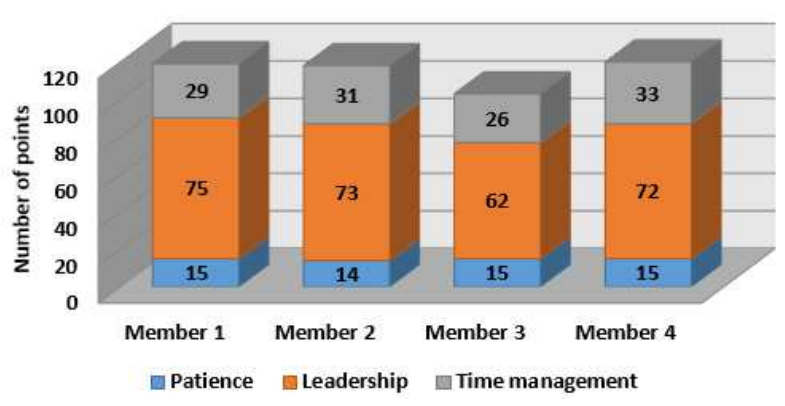

Fig. 9. Results of determining the level of soft skills after the project completion

The increase in the level of each of the soft skills is the confirmation of the effectiveness of the project phases, tasks, tools and project results. The increase in the time management skills, in students' opinion (result of interviews), is due to the use of special Office 365 services aimed at coordination of plans and role distribution among team members (for example, Calendar, Planner). The increase in leadership skills is due to the redistribution of groups subsequent to the results of the stages of tools analysis and the environmental design (students were able to identify or develop their own qualities), as well as in the process of preparing and presenting the results of group projects. The students were able to demonstrate (practice) patience and ability to listen to different points of view at the project implementation phase in teams, as well as during webinars, discussions and evaluation of the results.

In order to monitor and assess the results of the experiment, in addition to the online tests, questionnaires were developed to question students on three key components of a successful specialist: "Motivation for learning and development", "Soft skills", "Hard skills in the field of IT". The assessment of the level for each of the components was carried out according to the influence of the determined components of the training system on the formation of a successful specialist in the university environment: the content (in this context, the choice of the topic and the setting of the objectives of the project related to the field of study), methods (application of the project method), tools (tooling backup), forms of organization of teaching process (joint work). The level of influence was assessed on a sixpoint scale: 0 -absent; 5 -high.Table 2 shows the mean values of students' questionnaire results for each of the two streams.

Table 2

The assessment of the impact of the components of training system on the formation of a successful specialist

\begin{tabular}{|c|c|c|c|c|c|c|c|c|}
\hline \multirow{2}{*}{$\begin{array}{c}\text { Components } \\
\text { of the } \\
\text { successful } \\
\text { specialist }\end{array}$} & \multicolumn{2}{|c|}{ Theme } & \multicolumn{2}{|c|}{ Project method } & \multicolumn{2}{|c|}{ Tools } & \multicolumn{2}{|c|}{$\begin{array}{l}\text { Form of the } \\
\text { organization }\end{array}$} \\
\hline & $\begin{array}{c}\text { Stream } \\
1\end{array}$ & $\begin{array}{l}\text { Stream } \\
\quad 2\end{array}$ & $\begin{array}{c}\text { Stream } \\
1\end{array}$ & $\begin{array}{l}\text { Stream } \\
\quad 2\end{array}$ & $\begin{array}{c}\text { Stream } \\
1\end{array}$ & $\begin{array}{l}\text { Stream } \\
\quad 2\end{array}$ & $\begin{array}{c}\text { Stream } \\
1\end{array}$ & $\begin{array}{c}\text { Stream } \\
2\end{array}$ \\
\hline $\begin{array}{l}\text { Motivation to } \\
\text { learning and } \\
\text { development }\end{array}$ & 4.25 & 4.12 & 4.36 & 4.4 & 4.74 & 3.89 & 4.4 & 4.5 \\
\hline Soft skills & 3.02 & 2.89 & 4.76 & 4.68 & 4.54 & 4.27 & 4.8 & 4.7 \\
\hline $\begin{array}{l}\text { Hard skills in } \\
\text { the IT sphere }\end{array}$ & 4.19 & 3.87 & 3.82 & 3.78 & 4.8 & 4.17 & 3.3 & 3.4 \\
\hline
\end{tabular}


According to students' questionnaire results, one can conclude that the development of personal skills (soft skills) is greatly influenced by the application of the project methodology and the joint form of work (4.8 and 4.7). The theme of the project, which corresponds to the field of students' study, motivates to learning (4.25 points and 4.12). With regard to the impact of the project content on the development of hard skills, the students' opinions divided (4.19 and 3.87), which is explained (result of interviews) by the depth of the students' intelligence: those who formally fulfilled the tasks did not see the prospects of professional development, others - selected professional courses for non-formal learning, signed up for professional hackathons, etc.

As for the choice of tools (learning tools), students who have chosen a new SharePoint environment for the project implementation (stream 1), noted that the study of new tools in the process of fulfilling the project task contributed to raising their professional skills (students also began to take online courses on specialist disciplines on platforms like: Khan Academy: https://www.khanacademy.org/; Coursera: https://www.coursera.org/; Udemy: https://www.udemy.com/; Prometheus: https://prometheus.org.ua/), and the development of personal skills and motivation (groups of students coordinated their work with new tools, determined the perspectives of using SharePoint in their professional activity, evaluated Microsoft's proposals concerning the professional certification, onsite training).

The generalized results of the impact of each of these components of the specialist training system on the motivation to study and development, the development of soft skills and hard skills in the field of IT according to students' questionnaire are presented in Fig. 10

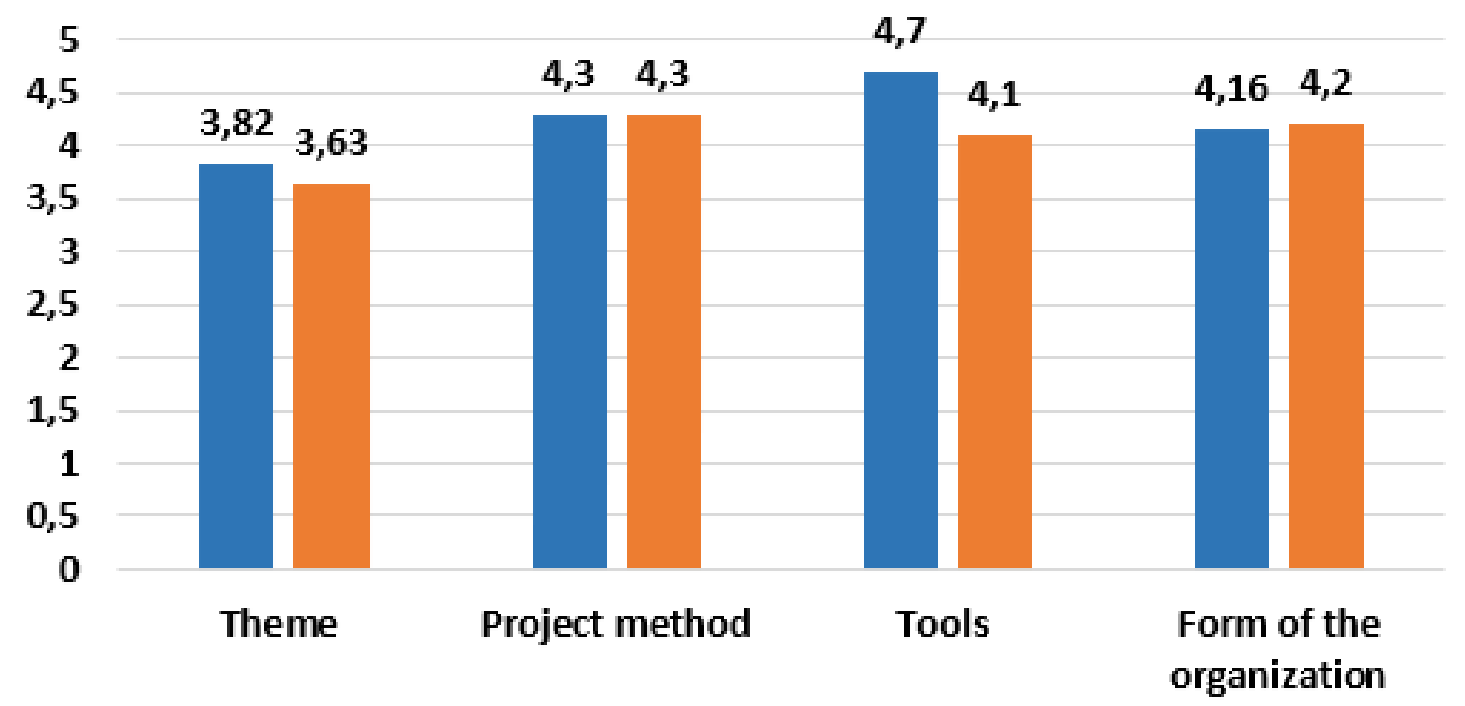

Stream 1 Stream 2

Fig. 10. Assessment of the impact of the specialist training system

All the students positively assessed (on average 4.1) a systematic approach to the organization of training. The use of Office 365 tools, which the students covered in the course of laboratory-based work while studying the subject Information Technologies (stream 2) reduced the time for project tasks and increased the probability of high quality of the results (determined by the results of interviewing). However, the use of the new tool, the SharePoint environment, was recognized by students as a more significant impact (stream 1).

The generalized diagram of the components of a successful specialist, based on the results of the students' questionnaire after the completion of the project, is presented in Fig. 11 


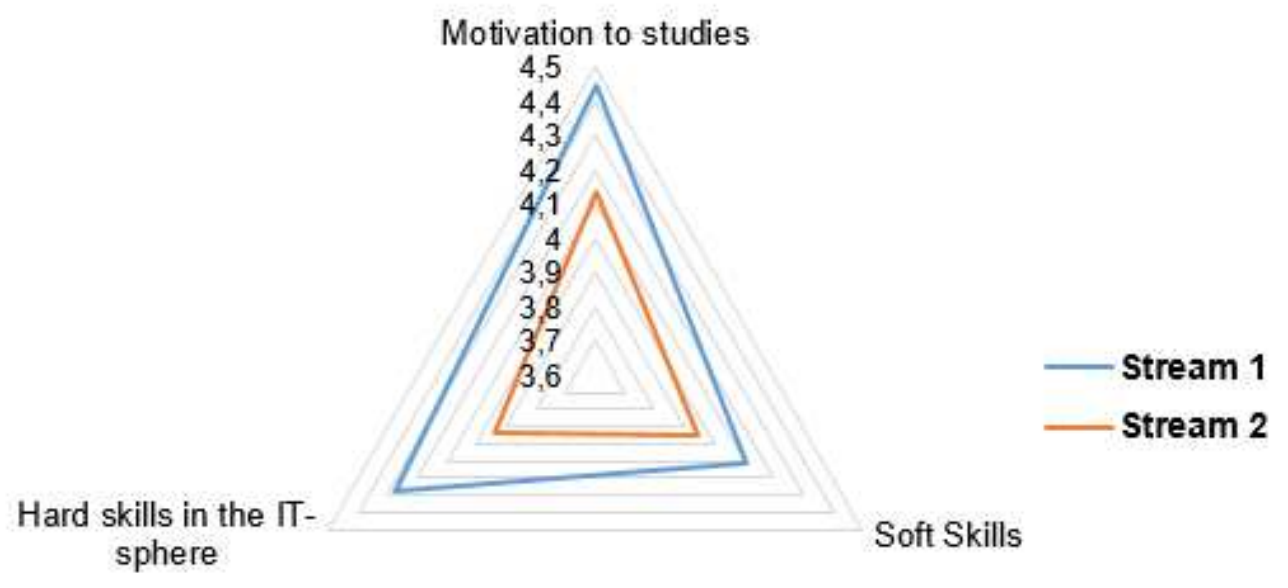

Fig. 11. Assessment of the students: impact of indicators on the formation of a successful specialist

On the basis of the presented results, one can assume that the use of new tools for solving project tasks in the field of study contributes to the motivation to learn and develop both professional skills and the personal ones.

The final questionnaires also encouraged students to voice their own suggestions on organizing training of future IT specialists at the Department of Information Technologies. Here are the most significant ones:

- to hold a joint project work at the final stage of each subject;

- to submit several projects for students to choose from;

- to involve employers' representatives in setting project tasks (in some subjects, outsourcing is possible);

- to attract experts to the process of assessing results (consulting) of the projects implementation, which will allow both to increase the motivation of the students and provide the possibility of traineeship, internship;

- to hold complex projects during the traineeship, which involve students from different courses and specialties.

\section{CONCLUSIONS AND FURTHER RESEARCH PERSPECTIVES}

Based on the results of the conducted experiment on the implementation of project technologies in teaching students (on the example of teaching the academic discipline Information technologies), we can draw the following conclusions:

1. The requirement to acquire both soft skills and hard skills in the process of preparing future IT specialists will update the need of attaching more flexibility and openness to the learning process, through the use of cloud technologies inclusive.

2. Cloud technologies, Office 365 in particular, have an impact on group forms of learning, as they facilitate collaboration and connectivity. The use of cloud technologies also affects the purpose-oriented, contextual and technological components of the teaching methodology.

3. Effectiveness of the implementation of project technology as a learning method depends on the formation of an e-environment, which includes services for planning activities, establishing communication and collaboration, resources for non-formal education, tools for evaluation and reflection. 
4. The use of SharePoint for designing an e-environment for the project implementation in a field of study contributes to the students' motivation to learn and develop both hard skills and soft skills. Thus, influencing the means, methods and forms of the organization of teaching process, cloud technologies thereby influence the methodological system of education in general.

The prospects of research in the organization of students' group projects involving ICT are seen in: studying and testing new $\mathrm{O} 365$ instruments for group projects (e.g. Teams), technology for organizing multidisciplinary projects using ICT, researching the impact of modern ICTs on the development of professional and personal competencies of students.

\section{REFERENCE (TRANSLATED AND TRANSLITERATED)}

[1] AlAlaa N. Tashkandi, Ibrahim M. Al-Jabri "Cloud computing adoption by higher education institutions in Saudi Arabia: an exploratory study”, Cluster Computing. №18:1527. [Online]. Available: https://link.springer.com/article/10.1007/s10586-015-0490-4. Accessed on: August 19, 2017 (in English)

[2] M. Alabbadi "Cloud computing for education and learning: education and learning as a service (ELaaS)". In: 14th International Conference on Interactive Collaborative Learning, pp. 589-594, 2011 (in English)

[3] Skendzic, B. Kovacic "Microsoft Office 365 - cloud in business environment", Proceedings of the 35th International Convention. $\quad$ MIPRO, [Online]. Available: http://ieeexplore.ieee.org/abstract/document/6240878/ Accessed on: August 19, 2017 (in English)

[4] M. Knoll "The project method: Its vocational education origin and international development", Journal of Industrial Teacher Education, №34 (3), pp. 59-80, 1997 (in English)

[5] T. Grady Roberts, Julie F. Harlin "The Project Method in Agricultural Education: Then and Now", Journal of Agricultural Education, v. 48, №3, pp. 46-56. [Online]. Available: http://files.eric.ed.gov/fulltext/EJ840131.pdf. Accessed on: August 19, 2017 (in English)

[6] O. Karabin "Project activity in formation of professional self-development of future specialists in the field of information technologies", "Young Scientist", v. 12.1 (40), 2016. [Online]. Available: http://molodyvcheny.in.ua/files/journal/2016/12.1/100.pdf. Accessed on: August 19, 2017 (in Ukrainian)

[7] N. Morse, L. Varchenko-Trotsenko "Using wiki-technology for the organization of the educational environment of a modern university", Open educational e-environment of the modern university, v. 1, pp. 115-125, 2015. [Online]. Available: http://openedu.kubg.edu.ua. Accessed on: August 19, 2017 (in Ukrainian)

[8] Adrian Ellison, Mauli Arora "Harnessing the power of Office 365 to provide a social learning environment through a new Student Portal" [Online]. Available: https://eunis2013journals.rtu.lv/article/view/eunis.2013.010. Accessed on: August 19, 2017 (in English)

[9] B. Worobec, R. Bryant "Using SharePoint as a limited learning management system", Journal of Computing Sciences in Colleges, v. 32, Issue 2, pp. 11-18, 2016.. [Online]. Available: http://dl.acm.org/citation.cfm?id=3015065. Accessed on: August 19, 2017 (in English)

[10] L. Atkins, C. Cole "An Introduction to Collaboration with SharePoint for First-year Business Students", Journal of Information Systems Education, v. 21(3), pp. 283-287. [Online]. Available: https://mail.ukr.net/attach/show/15000228521478154798/2/vol21-3pg283.pdf. Accessed on: August 19, 2017 (in English)

[11] Social competences of young specialists: results of the implementation of the international project TEMPUS “IMPRESS". [Online]. Available: http://www.edu-trends.info/tempus-impress/. Accessed on: August 19, 2017 (in Ukrainian)

[12] Stryuk, M. Stryuk, M. Koval "Methodical System of Teaching Informatics Disciplines Using Cloud Technologies", 2017. [Online]. Available: http://lib.iitta.gov.ua/1193/1/stryuk_v3.pdf. Accessed on: August 19, 2017 (in Ukrainian)

[13] Neal Brandi, Martz Ben "Foundations for a team oriented curriculum", Journal of Learning in Higher Education, v. 12, Issue 2, pp. 45-53, 2016. [Online]. Available: http://goo.gl/Tqk5KY. Accessed on: August 19, 2017 (in English)

[14] What is Soft Skills? What is the difference between Soft and Hard Skills? [Online]. Available: http://www.welldone.org.ua/shho-take-soft-skills-v-chomu-riznitsya-soft-i-hard-skills. Accessed on: August 19, 2017 (in Ukrainian)

[15] Time Management Skills Test. [Online]. Available: https://www.psychologytoday.com/tests/career/timemanagement-skills-test. Accessed on: August 19, 2017 (in English)

[16] J. Moreno "Sociometry. Experimental Method and Science about Society ", "Foreign Literature”, p. 255 , 1958 (in Russian) 
[17] How Do You Communicate? [Online]. Available: https://www.activia.co.uk/communication-skills-test. Accessed on: August 19, 2017 (in English)

[18] O. Glazunova, T. Voloshyna, "Hybrid Cloud-Oriented Educational Environment for Training Future IT Specialists", Information and Communication Technologies in Education, Research, and Industrial Applications, Communications in Computer and Information Science, v. 1614, pp. 157-167, 2016. [Online]. Available: http://ceur-ws.org/Vol-1614/paper_64.pdf. Accessed on: August 19, 2017 (in English)

[19] P.Black, "Formative Assessment and Curriculum Consequence", Curriculum and Assessment. Westport: Greenwood Publishing Group, Incorporated, pp.133-135, 2000. (in English)

[20] O. Glazunova, D. Kasatkin, O. Kuzminska, M. Mokriyev, A. Blozva, T. Voloshyna, T. Sayapina, Integration of educational resources and services of IT companies into the university's educational environment [collective monograph]. Kyiv, Ukraine: LLC "NVS Interservice", 2016 (in Ukrainian)

[21] O. Kuzminska, T. Voloshyna, T. Sayapina, "Learning Technologies in an Innovative Oriented Educational Environment: A Competency Approach and Educational Communications",Scientific Bulletin of the National University of Bioresources and Natural Resources of Ukraine, Series «Pedagogy. Psychology. Philosophy, Redcologist: Nikolayenko SM (Ed.) And others, vol. 253, no 2, pp. 50-64, 2016 (in Ukrainian)

\title{
E-СЕРЕДОВИЩЕ НА БАЗІ МICROSOFT SHARЕРОINT ДЛЯ ОРГАНІЗАЦЇ̈ ГРУПОВОЇ ПРОЕКТНОЇ РОБОТИ СТУДЕНТІВ ЗАКЛАДІВ ВИЩОЇ ОСВІТИ
}

\author{
Глазунова Олена Григорівна \\ доктор педагогічних наук, декан факультету інформаційних технологій \\ Національний університет біоресурсів і природокористування України, Київ, України \\ ORCID 0000-0002-0136-4936 \\ o-glazunova@nubip.edu.ua
}

\section{Кузьмінська Олена Геронтіївна}

кандидат педагогічних наук, доцент, завідувач кафедри інформаційних і дистанційних технологій Національний університет біоресурсів і природокористування України, Київ, України ORCID 0000-0002-8849-9648

o-kuzminska@nubip.edu.ua

\section{Волошина Тетяна Володимирівна}

асистент кафедри інформаційних і дистанційних технологій

Національний університет біоресурсів і природокористування України, Київ, України

ORCID 0000-0001-6020-5233

t-voloshina@nubip.edu.ua

\section{Саяпіна Таїсія Петрівна}

асистент кафедри інформаційних і дистанційних технологій

Національний університет біоресурсів і природокористування України, Київ, України ORCID 0000-0001-9905-4268

t_sayapina@nubip.edu.ua

\section{Корольчук Валентина Ігорівна}

асистент кафедри інформаційних і дистанційних технологій

Національний університет біоресурсів і природокористування України, Київ, України

ORCID 0000-0002-3145-8802

kololchuk@nubip.edu.ua
Анотація. Матеріали статті присвячені досвіду впровадження хмарних сервісів у процесі навчання студентів університету. Проаналізовано останні дослідження у галузі проектування та створення е-середовищ для організації групової проектної роботи. Розроблено модель е-середовища на базі Microsoft Sharepoint i наведено методику застосування хмарних сервісів Office 365 у єдиному е-середовищі для організації групової проектної роботи студентів. Розроблено критерії і підібрано інструменти оцінювання ефективності застосування е-середовища для організації групової проектної роботи. 
Запропоновано матеріали й аналіз результатів застосування методу проектів у навчанні дисципліни «Інформаційні технології» в НУБіП України. Визначено переваги використання е-середовища на базі Microsoft Sharepoint для організації проектної роботи студентів.

Ключові слова: вища школа; інформаційні технології Microsoft; хмарні сервіси; есередовище, метод проектів; групова робота; професійні та особистісні компетентності.

\title{
Э-СРЕДА НА ОСНОВЕ MICROSOFT SHAREPOINT ДЛЯ ОРГАНИЗАЦИИ ГРУППОВОЙ ПРОЕКТНОЙ РАБОТЫ СТУДЕНТОВ ВУЗОВ
}

\section{Глазунова Елена Григорьевна}

доктор педагогических наук, декан факультета информационных технологий Национальный университет биоресурсов и природопользования Украины, Киев, Украина o-glazunova@nubip.edu.ua ORCID 0000-0002-0136-4936

\section{Кузьминская Елена Геронтиивна}

кандидат педагогических наук, доцент, заведующий кафедрой информационных и дистанционных технологий Национальный университет биоресурсов и природопользования Украины, Киев, Украина ORCID 0000-0002-8849-9648

o-kuzminska@nubip.edu.ua

\section{Волошина Татьяна Владимировна}

ассистент кафедры информационных и дистанционных технологий Национальный университет биоресурсов и природопользования Украины, Киев, Украина ORCID 0000-0001-6020-5233

t-voloshina@nubip.edu.ua

\section{Саяпина Таисия Петровна}

ассистент кафедры информационных и дистанционных технологий Национальный университет биоресурсов и природопользования Украины, Киев, Украина ORCID 0000-0001-9905-4268

t_sayapina@nubip.edu.ua

\section{Корольчук Валентина Игоревна}

ассистент кафедры информационных и дистанционных технологий

Национальный университет биоресурсов и природопользования Украины, Киев, Украина ORCID 0000-0002-3145-8802

kololchuk@nubip.edu.ua

\begin{abstract}
Аннотация. Материалы статьи посвящены опыту внедрения облачных сервисов в процессе обучения студентов университета. Проанализированы последние исследования в области проектирования и создания электронной среды для организации групповой проектной работы. Разработана модель е-среды на базе Microsoft Sharepoint, и приведена методика применения облачных сервисов Office 365 в единой электронной среде для организации групповой проектной работы студентов. Разработаны критерии и подобраны инструменты оценки эффективности применения электронной среды для организации групповой проектной работы. Предложено материалы и анализ результатов применения метода проектов при обучении дисциплине «Информационные технологии» в НАУ Украины. Определены преимущества использования е-среды на базе Microsoft Sharepoint для организации проектной работы студентов.
\end{abstract}

Ключевые слова: высшая школа; информационные технологии Microsof;, облачные сервисы, е-среда; метод проектов; групповая работа; профессиональные и личностные компетентности.

\section{$(\mathrm{CC})$ BY-NC-SA}

This work is licensed under Creative Commons Attribution-NonCommercial-ShareAlike 4.0 International License. 